\title{
Analisis Pertumbuhan Vegetatif Tanaman Padi Gogo yang Diberi Berbagai Perlakuan Pupuk Fosfat dan Pupuk Hayati
}

\author{
Analysis of Vegetative Growth of Upland Rice Plants Given Various Treatments \\ of Phosphate Fertilizers and Biofertilizers \\ Hanny Hidayati Nafi' ah ${ }^{1}$ dan Hilmi Hardimansyah ${ }^{2}$ \\ 1) Program Studi Agroteknologi Fakultas Pertanian Universitas Garut, Garut \\ ${ }^{2)}$ Dinas Pertanian Kabupaten Garut, Indonesia \\ Jl. Raya Samarang No.52A, Tarogong Kaler, Kabupaten Garut, Jawa Barat 44151 \\ e-mail: hanny.hidayati@uniga.ac.id
}

\begin{abstract}
ABSTRAK
Pengembangan padi gogo sangat penting dilakukan untuk memenuhi kebutuhan beras, namun budidayanya terkendala kesuburan tanah terutama jika ditanam di lahan kering dataran rendah. Pengelolaan kesuburan tanah tidak hanya terbatas pada peningkatan kesuburan kimiawi, tetapi juga kesuburan fisik dan biologi tanah. Kendala kurang tersedianya unsur hara yang salah satunya adalah fosfat pada lahan kering perlu disiasati dengan aplikasi pupuk hayati pelarut fosfat yang dapat digunakan juga untuk mensubtitusi aplikasi pupuk anorganik sehingga mengurangi dampak dari residu pupuk tersebut. Tujuan dari penelitian ini adalah untuk menganalisis pertumbuhan vegetatif tanaman padi gogo yang diberi perlakuan pupuk fosfat dan pupuk hayati. Penelitian dilaksanakan di Desa Sukanagara Kecamatan Cisompet Kabupaten Garut. Padi gogo yang digunakan adalah varietas lokal dengan beras berwarna merah dan umur panen $250 \mathrm{HST}$. Waktu penelitian mulai bulan Nopember 2016 - Februari 2017. Rancangan percobaan yang digunakan adalah Rancangan Acak Kelompok (RAK) pola faktorial 4 x 4 yang terdiri dari faktor pupuk fosfat (P) dan pupuk hayati bakteri pelarut fosfat (B). Hasil penelitian menunjukkan terjadi interaksi antara pupuk fosfat dan pupuk hayati pada Laju Asimilasi Bersih dan Laju Tumbuh Tanaman, namun secara mandiri dosis pupuk fosfat dan pupuk hayati memberikan pengaruh yang berbeda nyata jumlah anakan, bobot kering, dan luas daun.
\end{abstract}

Kata Kunci : Varietas Situ Patenggang, Padi Gogo, Pupuk Hayati, dan Analisis Vegetatif.

\section{ABSTRACT}

Development of upland rice is very important to do to meet the needs of rice, but its cultivation is constrained by soil fertility, especially if planted in lowland dry land. Soil fertility management is not only limited to increasing chemical fertility, 
but also physical and biological fertility. Obstacles to the lack of nutrients, one of which is phosphate in dry land needs to be addressed with the application of phosphate solvent biological fertilizers which can be used also to substitute the application of inorganic fertilizers so as to reduce the impact of the fertilizer residue. The purpose of this study was to analyze the vegetative growth of upland rice plants treated with phosphate and biofertilizers. The study was conducted in Sukanagara Village, Cisompet Subdistrict, Garut Regency. The upland rice used is a local variety with red rice and a harvest age of 250 HST. The time of the study began in November 2016 - February 2017. The experimental design used was a 4 x 4 factorial Randomized Block Design (RBD) consisting of phosphate fertilizer factor $(P)$ and phosphate solvent $(B)$ bacterial biofertilizer. The results showed an interaction between phosphate fertilizer and biological fertilizer in the Clean Assimilation Rate and Plant Growth Rate, but independently the dose of phosphate fertilizer and biological fertilizer had a significantly different effect on the number of tillers, dry weight, and leaf area.

Keywords: Situ Patenggang Varieties, Gogo Rice, Biofertilizer, and Vegetative Analysis.

\section{PENDAHULUAN}

Kebutuhan beras semakin meningkat tapi luas lahan sawah semakin berkurang, karena itu pengembangan padi gogo perlu ditingkatkan (Munawaroh dkk., 2016). Namun lahan kering memiliki kendala kurang tersedianya unsur hara sehingga perlu pengoptimalan dalam pengelolaan kesuburan tanah dan pengoptimalan proses penyerapan unsur hara oleh tanaman. Pengelolaan kesuburan tanah tidak hanya terbatas pada peningkatan kesuburan kimiawi yang berasal dari pupuk anorganik, tetapi juga kesuburan fisik dan biologi tanah yang merupakan keuntungan dari pemberian pupuk organik sehingga tersedia lingkungan yang baik untuk pertumbuhan tanaman, dan kehidupan organisme tanah (Minardi, 2009). Maka dari itu, lahan kering untuk budidaya padi gogo diperlukan pupuk berimbang antara pupuk anorganik dan organik.

Pupuk hayati merupakan mikroorganisme hidup yang diberikan ke dalam tanah sebagai inokulan untuk membantu tanaman memfasilitasi atau menyediakan unsur hara tertentu bagi tanaman (Simanungkalit, 2001). Penggunaan pupuk hayati merupakan salah satu cara pengelolaan hara ramah lingkungan untuk mengurangi input pupuk anorganik, meningkatkan produktivitas dan kualitas hasil, serta melestarikan kesuburan tanah (Suwandi dkk., 2017). Bakteri pelarut fosfat merupakan pupuk hayati yang berfungsi menyediakan dan meningkatkan fosfat untuk tanaman (Marbun dkk., 2015). Unsur fosfat sangat diperlukan 
tanaman padi sejak awal pertumbuhan. Meskipun demikian, hanya sebagian kecil fosfat yang mampu diserap oleh tanaman (Hossain et al., 2008) dikarenakan fosfat mudah diikat oleh unsur Al, Ca, dan Fe. Keberadaan bakteri pelarut fosfat juga dapat digunakan untuk mensubtitusi aplikasi pupuk anorganik sehingga mengurangi dampak dari residu pupuk tersebut. Aplikasi bakteri pelarut fosfat dapat mensubtitusi hingga $50 \%$ dari kebutuhan pupuk anorganik pada tanaman sweet sorghum (Lumbantobing dkk., 2008) dan pada tanaman padi budidaya System of Rice Intensification (Puspitawati dkk., 2013). Kombinasi $\mathrm{P}_{2} \mathrm{O}_{5}$ dan bakteri pelarut fosfat dapat meningkatkan pertumbuhan dan hasil ubi jalar jika dibandingkan dengan aplikasi $\mathrm{P}_{2} \mathrm{O}_{5}$ tanpa bakteri pelarut fosfat (Sukmasari dkk., 2016).

Aplikasi pupuk hayati bakteri pelarut fosfat digunakan sebagai alternatif untuk pengoptimalan dalam proses penyerapan fosfat oleh tanaman. Tulisan ini bertujuan untuk menganalisis pertumbuhan vegetatif padi gogo yang diberi perlakuan berbagai dosis pupuk fosfat dan bakteri pelarut fosfat.

\section{BAHAN DAN METODE}

Penelitian dilaksanakan di Desa Sukanagara Kecamatan Cisompet Kabupaten Garut. Lokasi percobaan merupakan lahan kering dataran rendah. Waktu penelitian mulai bulan Nopember 2016 - Februari 2017. Padi gogo yang digunakan adalah varietas Situ Patenggang dengan beras berwarna merah dan umur panen 250 HST. Pupuk fosfat yang digunakan adalah SP-36. Dosis anjuran pupuk fosfat untuk padi gogo adalah $100 \mathrm{~kg} / \mathrm{ha}$. Pupuk hayati yang digunakan adalah bakteri pelarut fosfat yang mengandung Azotobacter dan Aspergilus.

Rancangan percobaan yang digunakan adalah Rancangan Acak Kelompok (RAK) pola faktorial 4 x 4 yang diulang 2 (dua) kali, faktor perlakuan terdiri dari faktor dosis pupuk fosfat (P) dan dosis bakteri pelarut fosfat (B). Dosis pupuk fosfat (P) terdiri dari 4 (empat) taraf yaitu $\mathrm{p}_{0}$ (tanpa pupuk fosfat), $\mathrm{p}_{1}$ (dosis $50 \%$ setara $80 \mathrm{~g} / \mathrm{plot}$ ), $\mathrm{p}_{2}$ (dosis $75 \%$ setara $120 \mathrm{~g} / \mathrm{plot}$ ). dan $\mathrm{p}_{3}$ (dosis $100 \%$ setara 160 $\mathrm{g} / \mathrm{plot}$ ). Dosis bakteri pelarut fosfat (B) terdiri dari 4 (empat taraf) yaitu $\mathrm{b}_{1}$ (dosis $0,1 \mathrm{~g} /$ lubang tanam), $\mathrm{b}_{2}$ (dosis $0,2 \mathrm{~g} /$ lubang tanam), $\mathrm{b}_{3}$ (dosis 0,3 g/ lubang 
tanam), dan $\mathrm{b}_{4}$ (dosis $0,4 \mathrm{~g}$ / lubang tanam). Ukuran plot yang digunakan adalah 3 m x $4 \mathrm{~m}$ menggunakan sistem legowo 2 dengan jarak tanam $30 \mathrm{~cm}$ x $30 \mathrm{~cm}$.

Pengamatan vegetatif yang dilakukan adalah laju asimilasi bersih (LAB), Laju Tumbuh Tanaman (LTT), jumlah anakan, bobot kering, dan luas daun. Uji analisis menggunakan ANOVA berdasarkan model statistik Rancangan Acak Kelompok Pola Faktorial. Untuk melihat nilai rata-rata yang berpengaruh digunakan Uji Jarak Berganda Duncan pada taraf 5\%. Data pengamatan dianalisis menggunakan software DSAASTAT ver. 1.101.

\section{HASIL DAN PEMBAHASAN}

Hasil analisis menunjukkan terjadi interaksi antara pupuk fosfat dan pupuk hayati pada Laju Asimilasi Bersih dan Laju Tumbuh Tanaman, namun secara mandiri dosis pupuk fosfat dan pupuk hayati memberikan pengaruh yang berbeda nyata jumlah anakan, bobot kering, dan luas daun.

\section{Laju Asimilasi Bersih}

Laju asimilasi bersih merupakan ukuran rata-rata efisiensi fotosintesis daun dalam suatu komunitas tanaman. Laju asimilasi bersih diukur pada interval 10 hari sekali. Pada analisis ini dilakukan pengukuran laju asimilasi bersih pada umur 40 HST sampai 50 HST dan pada umur 50 HST sampai 60 HST (Tabel 1).

Hasil analisis pada umur 40 HST sampai 50 HST terjadi interaksi pada kombinasi perlakuan $\mathrm{p}_{0} \mathrm{~b}_{4}, \mathrm{p}_{1} \mathrm{~b}_{3}$, dan $\mathrm{p}_{2} \mathrm{~b}_{2}$. Hasil analisis pada umur 50 HST sampai 60 HST terjadi interaksi pada kombinasi perlakuan $\mathrm{p}_{2} \mathrm{~b}_{2}$ dan $\mathrm{p}_{3} \mathrm{~b}_{1}$. Kombinasi perlakuan $\mathrm{p}_{2} \mathrm{~b}_{2}$ menunjukkan laju asimilasi bersih yang tinggi pada kedua analisis. Tingginya nilai laju asimilasi bersih diduga karena kurangnya daun tanaman yang saling menaungi. Bertambahnya jumlah daun yang diiringi dengan bertambahnya indeks luas daun maka makin banyak daun yang terlindungi karena daun akan saling menutupi yang menyebabkan penurunan nilai laju asimilasi bersih sepanjang musim pertumbuhan tanaman (Gardner et al., 1991). Laju asimilasi bersih tanaman padi gogo dapat ditingkatkan dengan aplikasi pupuk fosfat dosis $75 \%$ dan dosis bakteri pelarut fosfat $0,2 \mathrm{~g} /$ lubang tanam. 
Tabel 1. Analisis Laju Asimilasi Bersih Padi Gogo

\begin{tabular}{|c|c|c|c|c|c|c|c|c|}
\hline Umur & Perlakuan & $\begin{array}{c}\text { b1 (dosis } 0,1 \\
\text { g/ lubang } \\
\text { tanam) }\end{array}$ & & $\begin{array}{c}\text { b2 (dosis } 0, \\
\text { g/ lubang } \\
\text { tanam }\end{array}$ & & $\begin{array}{c}\text { b3 (dosis } 0, \\
\text { g/ lubang } \\
\text { tanam) }\end{array}$ & & $\begin{array}{c}\mathrm{b} 4 \text { (dosis } 0,4 \\
\mathrm{~g} / \text { lubang } \\
\text { tanam) }\end{array}$ \\
\hline \multirow{9}{*}{$\begin{array}{c}40-50 \\
\text { HST }\end{array}$} & apa & 0.000062 & $\mathrm{~d}$ & 0.000018 & $\mathrm{c}$ & 0.000004 & $\mathrm{a}$ & 0.000064 \\
\hline & fat) & $\mathrm{C}$ & & B & & A & & $\mathrm{D}$ \\
\hline & p1 (dosis & 0.000032 & b & 0.000005 & $\mathrm{a}$ & 0.000046 & d & 0.000006 \\
\hline & $50 \%$ setara & $\mathrm{C}$ & & A & & D & & B \\
\hline & 80 g/plot) & & & & & & & \\
\hline & & 0.000036 & c & 0.000077 & $\mathrm{~d}$ & 0.000017 & b & 0.000024 \\
\hline & $\begin{array}{l}75 \% 120 \\
\text { g/plot) }\end{array}$ & $\mathrm{C}$ & & D & & A & & B \\
\hline & p3 (dosis & 0.000014 & $\mathrm{a}$ & 0.000014 & b & 0.000023 & $\mathrm{c}$ & 0.000043 \\
\hline & $\begin{array}{l}100 \% 160 \\
\text { g/plot) }\end{array}$ & B & & A & & $\mathrm{C}$ & & D \\
\hline \multirow{8}{*}{$\begin{array}{c}50-60 \\
\text { HST }\end{array}$} & Perla & \multicolumn{2}{|c|}{$\begin{array}{c}\text { b1 (dosis } 0,1 \\
\text { g/ lubang } \\
\text { tanam) }\end{array}$} & \multicolumn{2}{|c|}{$\begin{array}{c}\mathrm{b} 2 \text { (dosis } 0,2 \\
\mathrm{~g} / \text { lubang } \\
\text { tanam }\end{array}$} & \multicolumn{2}{|c|}{$\begin{array}{c}\text { b3 (dosis } 0,3 \\
\text { g/ lubang } \\
\text { tanam) }\end{array}$} & $\begin{array}{c}\text { b4 (dosis } 0,4 \\
\text { g/ lubang } \\
\text { tanam) }\end{array}$ \\
\hline & $\begin{array}{l}\text { p0 (tanpa } \\
\text { pupuk fosfat) }\end{array}$ & $\begin{array}{c}0.000123 \\
\text { D }\end{array}$ & c & $\begin{array}{c}0.000106 \\
\mathrm{C}\end{array}$ & c & $\begin{array}{c}0.000065 \\
\mathrm{~A}\end{array}$ & c & $\begin{array}{c}0.000069 \\
\text { B }\end{array}$ \\
\hline & $\begin{array}{l}\text { p1 (dosis } \\
50 \% \text { setara }\end{array}$ & 0.000041 & $\mathrm{a}$ & 0.000068 & $\mathrm{a}$ & 0.000043 & $\mathrm{a}$ & 0.000085 \\
\hline & 80 g/plot) & A & & $\mathrm{C}$ & & B & & D \\
\hline & $\begin{array}{l}\mathrm{p} 2(\text { dosis } \\
75 \% 120\end{array}$ & 0.000072 & b & 0.000132 & d & 0.000061 & b & 0.000147 \\
\hline & g/plot) & B & & D & & A & & $\mathrm{C}$ \\
\hline & $\begin{array}{l}\text { p3 (dosis } \\
100 \% 160\end{array}$ & 0.000158 & d & 0.000075 & b & 0.000068 & d & 0.000120 \\
\hline & g/plot) & D & & B & & A & & $\mathrm{C}$ \\
\hline
\end{tabular}

Keterangan : Angka yang diikuti huruf besar yang sama secara horizontal dan huruf kecil yang sama secara vertikal tidak berbeda nyata menurut Uji Jarak Berganda Duncan taraf 5\%

\section{Laju Tumbuh Tanaman}

Laju tumbuh tanaman dipengaruhi oleh faktor biotik dan abiotik. Faktor biotik diantaranya serangan hama penyakit dan keberadaan mikroba penyubur tanah, sedangkan faktor abiotik diantaranya pupuk, sinar matahari dan curah hujan. Pada analisis ini dilakukan pengukuran laju asimilasi bersih pada umur 40 HST sampai 50 HST dan pada umur 50 HST sampai 60 HST (Tabel 2).

Hasil analisis pada umur 40 HST sampai 50 HST terjadi interaksi pada kombinasi perlakuan $p_{3} b_{3}$ dan $p_{3} b_{4}$. Hasil analisis pada umur 50 HST sampai 60 HST terjadi interaksi pada kombinasi perlakuan $\mathrm{p}_{2} \mathrm{~b}_{4}$ dan $\mathrm{p}_{3} \mathrm{~b}_{3}$. Kombinasi 
perlakuan $\mathrm{p}_{3} \mathrm{~b}_{3}$ menunjukkan laju tumbuh tanaman yang tertinggi. Laju tumbuh tanaman padi gogo dapat ditingkatkan dengan aplikasi pupuk fosfat dosis $100 \%$ dan dosis bakteri pelarut fosfat $0,3 \mathrm{~g}$ / lubang tanam. Hal ini menunjukkan semakin tinggi dosis pupuk fosfat yang diberikan dengan dosis optimal bakteri pelarut fosfat $0,3 \mathrm{~g}$ per lubang tanam, semakin besar nilai laju tumbuh tanaman padi gogo. P merupakan golongan unsur hara yang berfungsi untuk membentuk energi dalam tanaman diantaranya ATP (Taiz \& Zeiger, 2002). ATP merupakan salah satu energi yang digunakan tanaman untuk fotosintesis, jika semakin banyak ATP yang dihasilkan maka fotosintat yang dihasilkan semakin banyak sehingga akan meningkatkan laju tumbuh tanaman

Tabel 2. Analisis Laju Tumbuh Tanaman Padi Gogo

\begin{tabular}{|c|c|c|c|c|c|c|c|c|}
\hline Umur & Perlakuan & $\begin{array}{c}\text { b1 (dosi } \\
0,1 \mathrm{~g} / \\
\text { lubang } \\
\text { tanam) }\end{array}$ & & $\begin{array}{r}\mathrm{b} 2 \text { (dosis } \\
\mathrm{g} / \text { luban } \\
\text { tanam }\end{array}$ & & $\begin{array}{c}\mathrm{b} 3 \text { (dosis } 0 \\
\mathrm{~g} / \text { lubang } \\
\text { tanam) }\end{array}$ & & $\begin{array}{l}\mathrm{b} 4 \text { (dosis } 0,4 \\
\text { g/ lubang } \\
\text { tanam) }\end{array}$ \\
\hline \multirow{8}{*}{$\begin{array}{c}40-50 \\
\text { HST }\end{array}$} & $\begin{array}{l}\text { p0 (tanpa } \\
\text { pupuk }\end{array}$ & 0.00075 & $\mathrm{a}$ & 0.00062 & $\mathrm{a}$ & 0.00402 & $\mathrm{~d}$ & 0.00055 \\
\hline & fosfat) & A & & A & & B & & A \\
\hline & $\begin{array}{l}\text { p1 (dosis } \\
50 \% \text { setara }\end{array}$ & 0.00154 & $\mathrm{~b}$ & 0.00049 & $\mathrm{a}$ & 0.00032 & $\mathrm{a}$ & $0.00190 \mathrm{~b}$ \\
\hline & $80 \mathrm{~g} / \mathrm{plot})$ & B & & A & & A & & $\mathrm{C}$ \\
\hline & $\begin{array}{l}\mathrm{p} 2(\text { dosis } \\
75 \% 120\end{array}$ & 0.00187 & c & 0.00165 & $\mathrm{c}$ & 0.00170 & $\mathrm{~b}$ & 0.00208 \\
\hline & g/plot) & $\mathrm{BC}$ & & A & & $\mathrm{AB}$ & & $\mathrm{C}$ \\
\hline & $\begin{array}{l}\mathrm{p} 3(\text { dosis } \\
100 \% 160\end{array}$ & 0.00068 & a & 0.00101 & $\mathrm{~b}$ & 0.00236 & $\mathrm{c}$ & 0.00226 \\
\hline & g/plot) & A & & B & & $\mathrm{C}$ & & $\mathrm{C}$ \\
\hline \multirow{9}{*}{$\begin{array}{c}50-60 \\
\text { HST }\end{array}$} & Perlakuan & $\begin{array}{c}\mathrm{b} 1 \\
\text { (dosis } \\
0,1 \mathrm{~g} / \\
\text { lubang } \\
\text { tanam) }\end{array}$ & \multicolumn{3}{|c|}{$\begin{array}{l}\mathrm{b} 2 \text { (dosis } 0,2 \mathrm{~g} / \\
\text { lubang tanam }\end{array}$} & $\begin{array}{c}\mathrm{b} 3 \text { (dosis } 0 \\
\mathrm{~g} / \text { lubang } \\
\text { tanam) }\end{array}$ & & $\begin{array}{l}\text { b4 (dosis } 0,4 \\
\text { g/ lubang } \\
\text { tanam) }\end{array}$ \\
\hline & p0 (tanpa & 0.00169 & $\mathrm{a}$ & 0.00411 & $\mathrm{~b}$ & 0.00476 & $\mathrm{~b}$ & 0.00698 \\
\hline & $\begin{array}{l}\text { pupuk } \\
\text { fosfat) }\end{array}$ & A & & B & & B & & $\mathrm{C}$ \\
\hline & \multirow{6}{*}{$\begin{array}{l}\text { p1 (dosis } \\
50 \% \text { setara } \\
80 \text { g/plot) } \\
\text { p2 (dosis } \\
75 \% 120 \\
\text { g/plot) } \\
\text { p3 (dosis } \\
100 \% 160 \\
\text { g/plot) }\end{array}$} & 0.00226 & $\mathrm{a}$ & 0.00691 & $\mathrm{c}$ & 0.00353 & $\mathrm{a}$ & 0.00404 \\
\hline & & A & & $\mathrm{C}$ & & B & & B \\
\hline & & 0.00328 & $\mathrm{~b}$ & 0.00428 & $\mathrm{a}$ & 0.00704 & $\mathrm{c}$ & 0.01452 \\
\hline & & A & & B & & $\mathrm{C}$ & & $\mathrm{D}$ \\
\hline & & 0.00641 & c & 0.00781 & $\mathrm{~d}$ & 0.00876 & $\mathrm{~d}$ & 0.00760 \\
\hline & & A & & B & & $\mathrm{C}$ & & B \\
\hline
\end{tabular}


Keterangan : Angka yang diikuti huruf besar yang sama secara horizontal dan huruf kecil yang sama secara vertikal tidak berbeda nyata menurut Uji Jarak Berganda Duncan taraf 5\%.

\section{Jumlah Anakan, Bobot Kering, dan Luas Daun}

Analisis jumlah anakan, bobot kering, dan luas daun dapat dilihat pada Tabel 3. Hasil analisis menunjukkan terdapat pengaruh mandiri pupuk fosfat dan bakteri pelarut fosfat terhadap jumlah anakan, bobot kering, dan luas daun tanaman padi gogo. Aplikasi pupuk fosfat dengan penambahan bahan pupuk organik pada tanaman dapat meningkatkan parameter pertumbuhan vegetatif tanaman (El Sayed et al., 2011). Pemberian bakteri pelarut fosfat dapat meningkatkan pertumbuhan tanaman (Taniwan et al., 2016). Hormon yang dilepaskan oleh bakteri pelarut fosfat dapat mempengaruhi jumlah anakan, bobot kering, dan luas daun tanaman dengan cara mengaktifkan enzim dan meningkatkan elastisitas sel. Pengaruh hormon terhadap aktivitas enzimatis dan elastisitas sel dapat meningkatkan pembagian organ-organ tanaman yang memanfaatkan fotosintat (Gardner et al., 1991). Dosis pupuk fosfat $100 \%$ berpengaruh pada bobot kering dan luas daun padi gogo. Dosis bakteri pelarut fosfat $0,3 \mathrm{~g} /$ lubang tanam berbeda nyata dengan dosis lainnya terhadap jumlah anakan, bobot kering, dan luas daun padi gogo.

Tabel 3. Analisis Jumlah Anakan, Bobot Kering, dan Luas Daun Padi Gogo

\begin{tabular}{|c|c|c|c|c|c|}
\hline Perlakuan & $\begin{array}{c}\text { Jumlah } \\
\text { Anakan }\end{array}$ & $\begin{array}{l}\text { Bobot } \\
\text { Kering }\end{array}$ & & \multicolumn{2}{|c|}{ Luas Daun } \\
\hline Pupuk Posfat (P) & & & & & \\
\hline p0 (tanpa pupuk fosfat) & $3.88 \mathrm{a}$ & 4.94 & $\mathrm{a}$ & 912.75 & $\mathrm{a}$ \\
\hline p1 (dosis $50 \%$ setara $80 \mathrm{~g} / \mathrm{plot})$ & $4.75 \mathrm{a}$ & 14.44 & $\mathrm{~b}$ & 1491.76 & $a b$ \\
\hline $\mathrm{p} 2$ (dosis $75 \% 120 \mathrm{~g} / \mathrm{plot})$ & $4.63 \mathrm{a}$ & 11.71 & $\mathrm{~b}$ & 1309.10 & $a b$ \\
\hline p3 (dosis $100 \% 160$ g/plot) & $4.38 \mathrm{a}$ & 12.71 & $b$ & 1676.18 & $b$ \\
\hline \multicolumn{6}{|l|}{ Bakteri Pelarut Posfat (B) } \\
\hline b1 (dosis $0,1 \mathrm{~g} /$ lubang tanam) & $2.88 \mathrm{a}$ & 6.85 & $\mathrm{a}$ & 1008.88 & $\mathrm{a}$ \\
\hline b2 (dosis $0,2 \mathrm{~g} /$ lubang tanam & $4.13 \mathrm{ab}$ & 10.04 & $a b$ & 967.01 & a \\
\hline b3 (dosis 0,3 g/ lubang tanam) & $6.00 \mathrm{c}$ & 14.97 & $\mathrm{~b}$ & 1972.49 & $\mathrm{~b}$ \\
\hline b4 (dosis $0,4 \mathrm{~g} /$ lubang tanam) & $4.63 \mathrm{bc}$ & 11.95 & $\mathrm{~b}$ & 1441.41 & $\mathrm{ab}$ \\
\hline
\end{tabular}

Keterangan : Angka yang diikuti huruf yang sama pada setiap kolom tidak berbeda nyata menurut uji jarak berganda Duncan taraf 5\%. 


\section{KESIMPULAN}

Terjadi interaksi antara dosis pupuk fosfat $75 \%$ dan dosis bakteri pelarut fosfat $0,2 \mathrm{~g} /$ lubang tanam pada laju asimilasi bersih, dan antara dosis pupuk fosfat $100 \%$ dan dosis bakteri pelarut fosfat $0,3 \mathrm{~g} /$ lubang tanam pada laju tumbuh tanaman. Secara mandiri dosis pupuk fosfat $100 \%$ memberikan pengaruh yang berbeda nyata pada bobot kering dan luas daun, sedangkan dosis pupuk hayati 0,3 $\mathrm{g} /$ lubang tanam memberikan pengaruh yang berbeda nyata jumlah anakan, bobot kering, dan luas daun.

\section{UCAPAN TERIMA KASIH}

Penulis mengucapkan terima kasih kepada Fakultas Pertanian Universetas Garut yang telah membantu dalam pendanaan penelitian ini, dan kepada Bapak Kartiwa Ketua Kelompok Tani Tunas Karya Mandiri Desa Sukanagara Kecamatan Cisompet Kabupaten Garut yang telah menyediakan lahan serta membantu selama proses penanaman.

\section{DAFTAR PUSTAKA}

El Sayed, H. E. A., Saif, E. D. A., Ezzat, S., \& El Morsy, A. H. A. (2011). Responses of productivity and quality of sweet potato to phosphorus fertilizer rates and application methods of the humic acid. Journal of Agricultural Science and Soil Science, 1(9), 383-393.

Gardner, F. P., Pearce, R. B., \& Mitchell, R. L. (1991). Fisiologi Tanaman Budidaya. (H. Susilo \& S. Subiyanto, Eds.) (1st ed.). Jakarta: UI-Press.

Hossain, M. M., Alam, M. S., Talukder, N. M., Chowdhury, M. A. H., \& Sarkar, A. (2008). Effect of Phosphate Solubilizing Bacteria and Different Phosphatic Fertilizers on Nutrient Content of Rice. J. Agrofor. Environ, 2(1), $1-6$.

Lumbantobing, E. L. N., Hazra, F., \& Anas, I. (2008). Uji Efektivitas Bio-Organic Fertilizer ( Pupuk Organik Hayati ) dalam Mensubstitusi Kebutuhan Pupuk Anorganik pada Tanaman Sweet Sorghum [ Sorghum bicolor ( L .) Moench ]. Jurnal Tanah Dan Lingkungan, 10(2), 72-76.

Marbun, S., Sembiring, M., \& Bintang, B. (2015). Aplikasi Mikroba Pelarut Fosfat dan Bahan Organik untuk Meningkatkan Serapan P dan Pertumbuhan Kentang pada Andisol Terdampak Erupsi Gunung Sinabung. Jurnal Agroteknologi, 4(1), 1651-1658. 
Minardi, S. (2009). Optimalisasi pengelolaan lahan kering untuk pengembangan pertanian tanaman pangan. Retrieved from https://core.ac.uk/download/pdf/12345853.pdf

Munawaroh, L., Sulistyono, E., \& Lubis, I. (2016). Karakter Morfologi dan Fisiologi yang Berkaitan dengan Efisiensi Pemakaian Air pada Beberapa Varietas Padi Gogo. J. Agron Indonesia, 44(1), 1-7.

Sukmasari, M. D., Hamdani, J. S., Waluyo, B., Karuniawan, A., Majalengka, P. U., Padjadjaran, P. U., ... Brawijaya, U. (2016). Efek Kombinasi Pupuk Fosfat dan Bakteri Pelarut Fosfat dan Bakteri Pelarut Fosfat terhadap Indeks Pertumbuhan Fisiologi Lima Varietas Ubi Jalar (Ipomoea batatas (L.) Lam). Pangan, 25(3), 201-210.

Taiz, L., \& Zeiger, E. (2002). Plant Physiology (Third). Sinauer: Sinauer Associates.

Taniwan, S., Suryanto, D., \& Nurwahyuni, I. (2016). Isolasi dan Karakterisasi Parsial Bakteri Pelarut Fosfat dari Guano Gua Kampret dan Uji Kemampuannya dalam Meningkatkan Pertumbuhan Tanaman. Jurnal Biosains, 2(2), 82-90 